\title{
MODIFYING DOMINO CARDS TO INCREASE STUDENTS' UNDERSTANDING OF THE USE OF POSSESSIVE ADJECTIVE AT JUNIOR HIGH SCHOOL
}

\author{
M. Labib Al Halim \\ Pendidikan Bahasa Inggris, Universitas Billfath
}

INFO ARTIKEL

Diterima:14-02-2020

Disetujui:17-02-2020

\begin{abstract}
Abstrak: Penelitian ini bertujuan untuk mengetahui penggunaan permainan kartu domino yang dimodifikasi sebagai media untuk meningkatkan pemahaman siswa tentang penggunaan kata sifat posesif. Penelitian ini menggunakan desain penelitian tindakan kelas yang diajukan oleh Ferrance. Subjek penelitian ini adalah siswa sekolah menengah pertama di MTs. Bahrul Ulum Turi Lamongan yang terdiri dari 28 siswa. Hasil penelitian menunjukkan bahwa media kartu domino dapat merangsang siswa untuk aktif dan lebih memperhatikan pelajaran yang diberikan. Ini secara efektif mempengaruhi prestasi siswa. Data yang didapat menunjukkan bahwa prestasi siswa meningkat secara signifikan dari 57,86 di tes awal menjadi 76,57 di tes akhir. Dengan demikian, dapat disimpulkan bahwa kartu domino yang dimodifikasi dapat meningkatkan pemahaman siswa tentang penggunaan kata sifat posesif. Media kartu domino juga bisa merangsang siswa (usia muda) untuk aktif dan lebih memperhatikan pelajaran yang diberikan.
\end{abstract}

Kata Kunci:

Abstract: This research aimed to know the use of modified domino card game as media to increase students understanding of the application of possessive adjective. The method of this research was classroom action research design proposed by Possessive Adjective, Students' Understanding, Ferrance. The subjects were students of junior high school at Students' Achievement MTs. Bahrul Ulum Turi Lamongan consisted of 28 students. The result showed that media domino card could stimulate students to be active and pay more attention. It effectively affected students' achievement. The data showed that students' achievement increase significantly from 57.86 in preliminary test to 76.57 in final test. Thus, it could be concluded that modified domino card could increase students understanding of the use of possessive adjective. It could also stimulate young students to be active and pay more attention to the lesson given.

Alamat Korespondensi:

M. Labib Al Halim

Universitas Billfath

Komplek PP Al-Fattah Siman, Sekaran, Lamongan

Surel: labibhalim27@gmail.com 
Cards are a popular game among children, teenagers and adults. Card media is used in learning through a game. Games as learning media involve students in the process of experience and at the same time live up to challenges, get inspired, be motivated, be creative and encourage students to interact with others students during this game (Utomo, 2013). A game can be categorized as something fun. However, it can be modified as a strategy in learning. The teacher can make specific objectives and rules during the game which meant that the teacher as an educator should innovate to help the students to express their participation in the learning process (lee, 1997). For this reason, learning media in the form of domino card is needed to increase students' understanding of the use of a possessive adjective.

Domino card media is adopted from domino games in general. The difference is that the cards are modified based on the materials of a possessive adjective. Students are trained to analyse the cards and match them. In this modified domino card, students are also invited to recognize possessive adjective that is on the card, then guess which card match with the card they have. Domino is a series of games that were applied in the learning process. domino means to match the word, sentence, or picture to their meaning and was played by a group of players. (Harmer, 2007), states that students should analyse the words in context to see the way they are used. In this case, a teacher should give stimulus and train students related to the strategy implemented in the class to help them understand and remember the words. To create interesting learning activities in teaching, the teacher should have the ability to choose and apply the appropriate learning method for their learners. The goal is to makes students easier to receive and understand the materials (Halim, 2019). Thus, it should be noted that the game used is not just a game for having fun and entertainment. However, it was also to attract students' motivation in learning especially in possessive adjective material.

(Wing, 2015) stated that domino card games were an effective strategy to improve students' vocabulary mastery. The data obtained also confirmed that domino games also stimulated students' interest in learning. (Putri, 2018) conducted research on the use of domino card to improve students' vocabulary. It showed that the domino card game was an effective game to increase students' vocabulary mastery. (Rufaidah, Martiah, and Kodri, 2019) applied for domino card in learning process. The result showed that the domino card effect significantly on students' achievement.

English is a subject of local content at junior high school. The Ministry of National Education states that English is a verbal and written communication tool. The ability to communicate in a complete sense is the ability to understand and produce oral or written texts that are realized in four language skills, namely listening, speaking, reading, and writing. One of the materials existed was possessive adjective and possessive pronoun. These parts of grammar were the basic grammatical rules which should be mastered by the students who learn English as their foreign language. Possessive adjective and possessive pronoun could not be ignored in communication either in speaking or writing. In reality, the students were still confused with the use of possessive adjective and pronoun. Probably they still did not understand the correct rules of implementing possessive adjective and pronoun.

Based on the problem above, a teacher needs an innovation strategy to solve the problem. Cooperative learning probably is an effective way for students at junior high school. Cooperative learning could build students' motivation and interest in learning which was effective to increase students' achievement (Halim, 2019). Therefore, the researcher interested in using domino card to increase 
KARANGAN: Jurnal Kependidikan, Pembelajaran, dan Pengembangan, Vol 02, No 01, Bln Feb, Tahun 2020, Hal 71 - 79

students' understanding on the use of possessive adjective for junior high school students.

\section{Review Literature}

Game is an activity which has specific rules for playing it. Reward and punishment are also enforced during playing game. A Reward is usually given to the winner of the game, while punishment is given to the player who does not follow and obey the rules. There are two kinds of game, those are competitive and cooperative game (Hadfield, 2001). Competitive game is a game played by players or a team that race to be the winner, while cooperative game is a game played by that teams or group of persons that work together towards a common goal. A game has many factors. In learning, the game can help students understand the materials and have fun. Game-based learning can create an interactive learning environment and build students' motivation, enjoyment. They believed that this approach can better motivate students because it present entertainment which the students mostly like (Tang \& Hanneghan, n.d.).

Domino is a series of card games existed almost around the word. In learning, the domino card is modified to picture and word or word with its meaning. (Wetrup, 2000) stated that domino card is played by matching sets of cards. Thus, it needs some players around five persons. Working in a group is an effective way of giving a task. the students can share their argument, knowledge, idea and remind each other (Halim, 2018). Domino card is easy games prepared for learning activities. It also has big advantages to being fun, competitive, and certainly memorable (Wing, 2015).
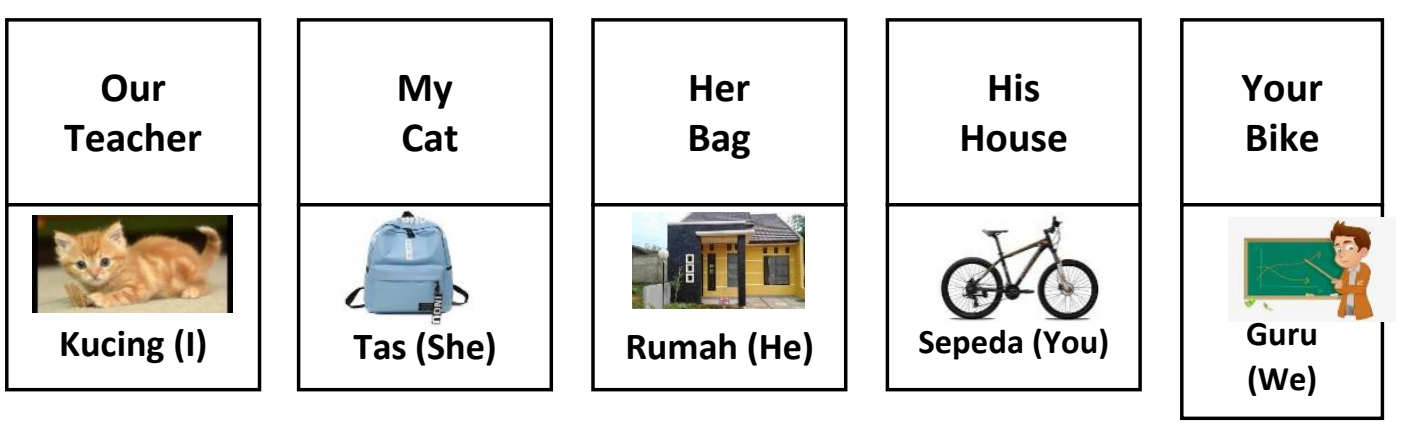

Picture 1 Examples of modified domino game

\section{Steps of Domino Card Game}

The researcher set six steps to play modified domino card as follow:

1. The teacher gave an instruction related to the ruses of the game and how to play the game.

2. The teacher divided the student into a group of people (based on the situation)

3. The teacher gave a set of modified domino that has been prepared before to each group.

4. Each group shuffled the cards and distributed them to their members.

5. The group who finished fastest than others and did correct matching is the winner of the game

6. The teacher asked every single student to remember the use of possessive adjective.

\section{Advantage of Domino Card Game}


Several advantages of implementing domino card games:

1. It stimulates students' interest

2. It stimulates students' attention to the specific structure

3. It stimulates students to be active

4. It helps student easily understand the material

\section{Conceptual Framework of this Research}

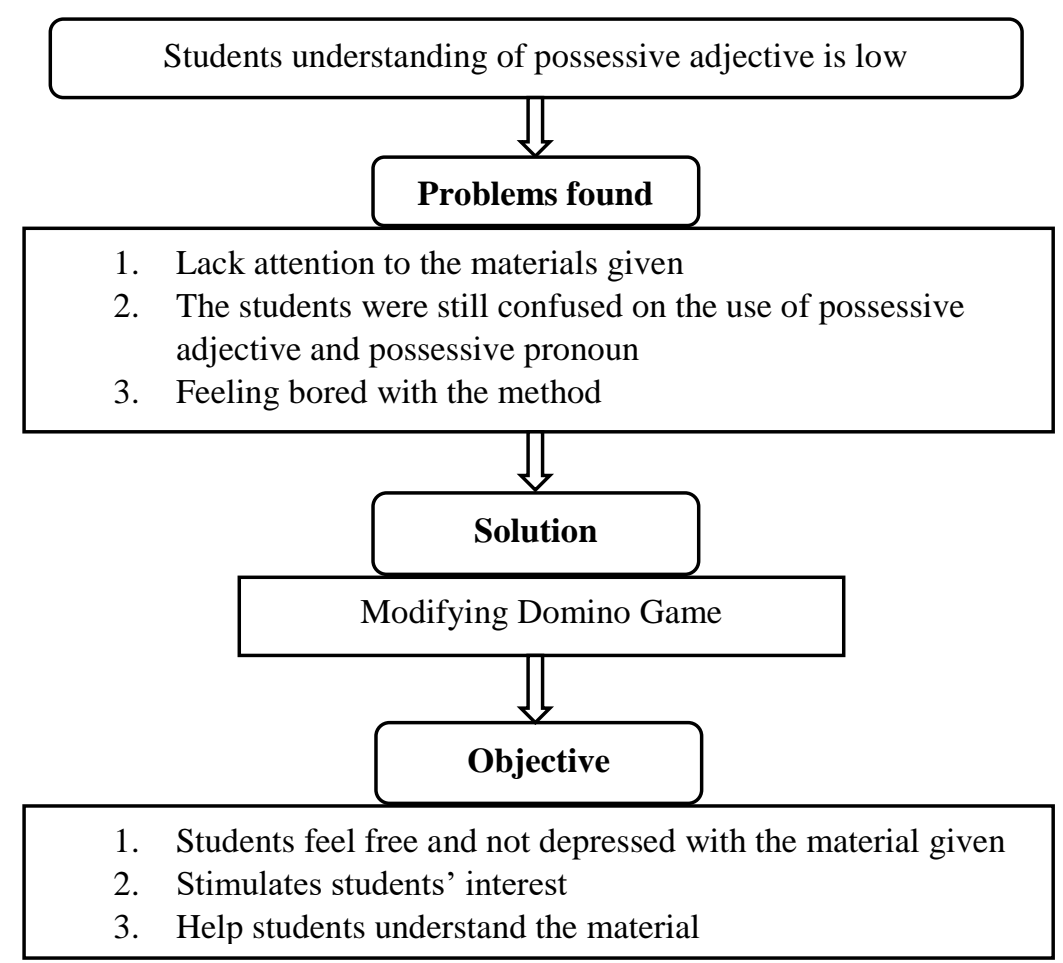

Table 1 Conceptual framework of the research

\section{Method}

The researcher applied classroom action research design. The data used in this research were quantitative and qualitative data. Data qualitative was taken from interview and observation during the learning process, while data quantitative was taken from the result of evaluation of learning. The researcher used preliminary test and final test to evaluate the students. Preliminary test was conducted to know students' competence of understanding possessive adjective, whereas the final test was used to find out the extent of students' understanding in possessive adjective. 
KARANGAN: Jurnal Kependidikan, Pembelajaran, dan Pengembangan, Vol 02, No 01, Bln Feb, Tahun 2020, Hal 71 - 79

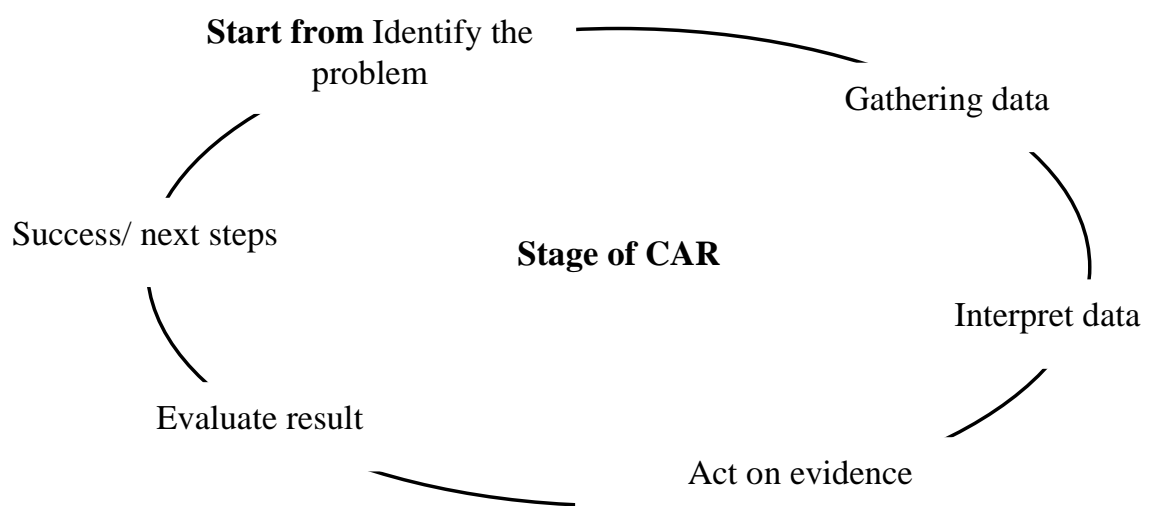

Figure 1 Action research stage adopted from(Ferrance, 2000)

\section{Subject of the Study}

The subject of this study was $7^{\text {th }}$ grade of junior high school students of MTs. Bahrul Ulum Turi Lamongan consisted of 28 students. The researcher set as the subject of study because it was possible to use random sampling from the population. The subjects consisted of 12 male students and 16 female students with an average of 12 years old.

\begin{tabular}{cccccc}
\hline \multirow{2}{*}{ Total subjects } & \multicolumn{3}{c}{ Gender } & \multicolumn{3}{c}{ Age } \\
\cline { 2 - 6 } 28 Students & Male & Female & 11 & 12 & 13 \\
\hline \multirow{2}{*}{28} & 12 & 16 & 1 & 24 & 3 \\
\hline
\end{tabular}

Table 2 The details of subjects of study

\section{Procedure}

The procedure of this research followed Ferrances' stage of action research. Before conducting this research, the researcher started to identify the problem happen in learning process. The researcher did observation and interviewed the students to get the data. After collecting the data, the researcher analysed and interpreted the data in the form of qualitative data. Based on the problem understood, the researcher began to plan the action. In this research, the researcher applied Domino card game as the media of teaching. The card has been modified based on the material. The researcher implemented this media for three different times. In the next meeting, the researcher gave final test to measure the implementation of the modified domino card game. The data was in the form of quantitative data. The last step was evaluating the data. The data got from final test compared with the data of the preliminary test.

\section{Data Collection and Analysis}

The data was collected from observation, interview, and test. The data gotten from the observation and interview were analysed and interpreted as qualitative data. While the data obtained from the test were analysed statistically using SPPSS 20. The data were analysed using descriptive statistics and paired sample T-test. It was to know the different score before implementing domino card and after having implemented domino card. 


\section{Result and Discussion}

\section{Preliminary Test}

The data got from the preliminary test as follows:

\begin{tabular}{|lccccc|}
\multicolumn{7}{|c}{ Descriptive Statistics } \\
\hline & N & Minimum & Maximum & Mean & $\begin{array}{c}\text { Std. } \\
\text { Deviation }\end{array}$ \\
\hline Preliminary Test & 28 & 44 & 72 & 57.86 & 8.674 \\
Valid N (listwise) & 28 & & & & \\
\hline
\end{tabular}

Table 3 Descriptive statistics of preliminary test

The score of students' tests in the preliminary test was analysed statistically using descriptive statistics. The data was indicated that the minimum score was 44 and the maximum score was 72 with an average score was 57.86. it meant that average students had the right answer of 14 questions from a total of 25 questions. The details could be seen in the diagram below:

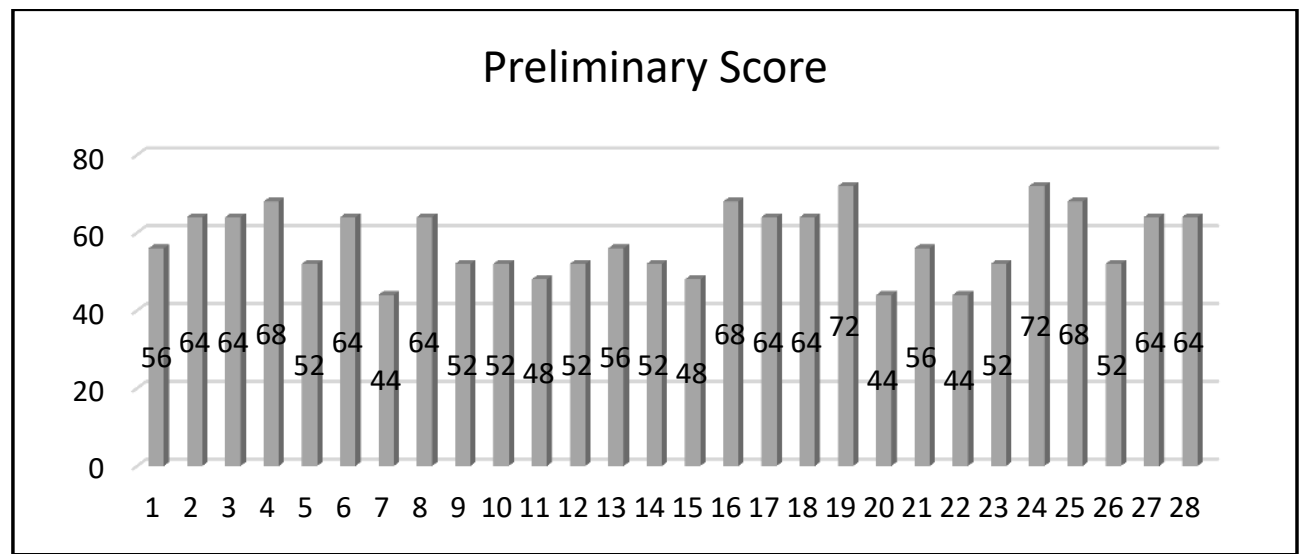

Diagram 1 The details of students' score in the preliminary test

\section{Final Test}

The data got from the final test as follows:

Descriptive Statistics

\begin{tabular}{lccccc}
\hline & N & Minimum & Maximum & Mean & Std. Deviation \\
\hline Preliminary Test & 28 & 68 & 88 & 76.57 & 7.198 \\
Valid N (listwise) & 28 & & & & \\
\hline Talie & & & &
\end{tabular}

Table 4 Descriptive statistics of the final test

From the table above, it represented that students' score was increased from the preliminary test. Based on the data gotten, the minimum score was 68 and the maximum score was 88 with an average score was 76.57 . The details score was as follows: 
KARANGAN: Jurnal Kependidikan, Pembelajaran, dan Pengembangan, Vol 02, No 01, Bln Feb, Tahun 2020, Hal 71 - 79

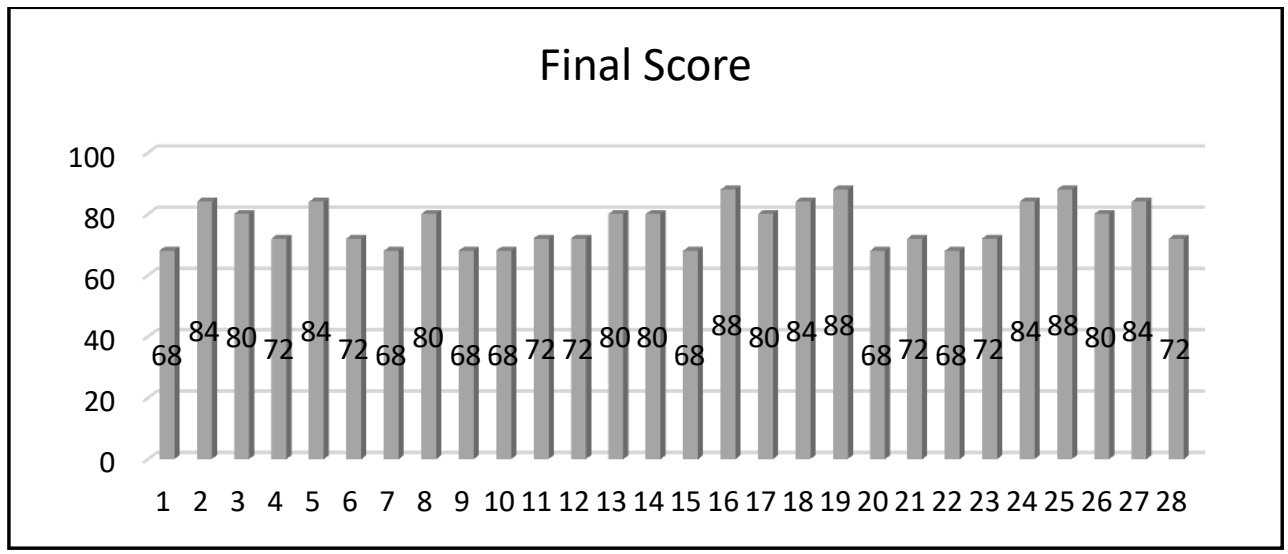

Diagram 2 The details of students' score in the final test

\section{Paired Sample T-test}

The result of paired sample T-test analysis was as follows:

Paired Samples Statistics

\begin{tabular}{lllccc}
\hline & Mean & N & Std. Deviation & $\begin{array}{c}\text { Std. Error } \\
\text { Mean }\end{array}$ \\
\hline \multirow{2}{*}{ Pair 1 } & Preliminary Test & 57.86 & 28 & 8.674 & 1.639 \\
& Final Test & 76.57 & 28 & 7.198 & 1.360 \\
\hline
\end{tabular}

Table 5 Paired sample statistics

From the result of T-test analysis above, the data showed that there was a high enhancement of mean score between the preliminary test and final test. It meant that the implementing of modified domino card had an important role in increasing students' score of tests. The details showed that the enhancement of students score was 18.714 and the Sig. value was 0.000 lower than 0.05 as significant level. Thus, it could be concluded that the implementing of modified domino card was an effective way to increase students' understanding of the use of possessive adjective at junior high school. The result of the analysis could be seen in the table and diagram below:

Paired Samples Test

\begin{tabular}{|c|c|c|c|c|c|c|c|c|c|}
\hline & & \multicolumn{5}{|c|}{ Paired Differences } & $\mathrm{t}$ & $\mathrm{df}$ & Sig. (2-tailed) \\
\hline & & \multirow[t]{2}{*}{ Mean } & \multirow[t]{2}{*}{$\begin{array}{c}\text { Std. } \\
\text { Deviati } \\
\text { on }\end{array}$} & \multirow[t]{2}{*}{$\begin{array}{l}\text { Std. } \\
\text { Error } \\
\text { Mean }\end{array}$} & \multicolumn{2}{|c|}{$\begin{array}{c}95 \% \\
\text { Confidence } \\
\text { Interval of the } \\
\text { Difference }\end{array}$} & & & \\
\hline & & & & & $\begin{array}{c}\text { Low } \\
\text { er }\end{array}$ & Upper & & & \\
\hline Pair 1 & $\begin{array}{l}\text { Prelimi } \\
\text { nary } \\
\text { Test - } \\
\text { Final } \\
\text { Test }\end{array}$ & -18.714 & 6.353 & 1.201 & $\begin{array}{r}- \\
21.1 \\
78\end{array}$ & 16.251 & $\begin{array}{r}- \\
15 . \\
588\end{array}$ & 27 & .000 \\
\hline
\end{tabular}

Table 6 Paired sample T-test 


\section{Prelimimary Test \& Final Test}

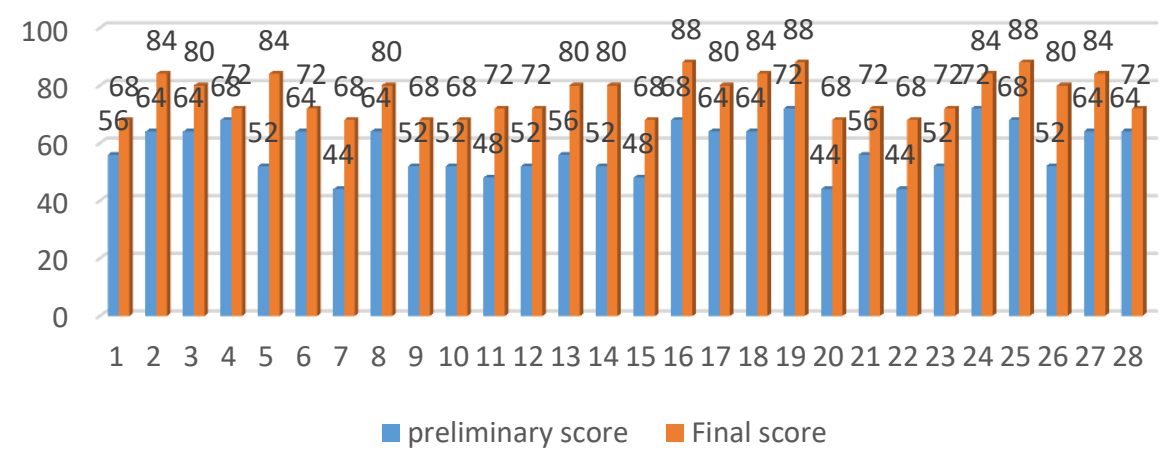

Diagram 2 The different of students' preliminary score and the final score

\section{Conclusion}

Based on the result above, this research showed that the implementing of modified domino card game could increase students' understanding of the use of possessive adjective at junior high school. Young learner wanted to feel free in the learning process. Therefore, media domino cards could stimulate students' to be active and pay more attention to the specific subject. A teacher should have an innovation strategy to solve the problem in the learning process. Media of domino card could be a solution for a teacher in teaching especially for the young learner. It could also be tried in other subjects such as grammar and vocabulary.

\section{References}

Dananjaya, Utomo. (2013). Active Learning Media. Bandung: Shades of Scholar

Deighton,L. (1997).Games for Language Learning, Cambridge: Cambridge University Press.

Ferrance, E. (2000). Themes in education: Action research. Brown University: Educational Alliance, 34(1).

Hadfield, et. al. 2001. Elementary Vocabulary Games. Malaysia: Longman, Pearson Education.

Halim, M. L. Al. (2018). The Effectiveness of Pair Work and Group Work on Students' Achievement in Giving Writing Task. JALIE: Journal of Applied Linguistics and Islamic Education, 02(02), 225-253. https://doi.org/https://dx.doi.org/10.33754/jalie.v2i2.181

Halim, M. L. Al. (2019). INCREASING ENGLISH ACHIEVEMENT THROUGH TWO STAY- TWO STRAY ( TS-TS ) METHOD. KARANGAN: Jurnal Kependidikan, Pembelajaran, Dan Pengembangan, 01(02), 102-109.

Harmer, Jeremy. 2007. How to Teach English. Harlow: Pearson Education Limited.

Latief, Mohammad Adnan. (2011). Research Method on Language Learning. An Introduction. Malang: Universitas Negeri Malang 
KARANGAN: Jurnal Kependidikan, Pembelajaran, dan Pengembangan, Vol 02, No 01, Bln Feb, Tahun 2020, Hal 71 - 79

Lie, Anita. (2004). Cooperative Learning: Mempraktikkan Cooperative Learning di Ruang-Ruang Kelas. Jakarta: Gramedia

Putri, I.R.P. (2019). The effectiveness of using modified domino card game toward students' vocabulary mastery at seventh grade of mts assyafi'iyah gondang tulungagung in the academic year 2016/2017. IAIN Tulungagung http://repo.iain-tulungagung.ac.id/id/eprint/8173

Rufaidah, E. Martiah. A \& Kodri. (2019) The effect of domino game learning media on student learning achievements. JRBEE: Journal of Reseacrh in Business, Economics, and Education. 01(02), 239-246

Tang, S., \& Hanneghan, M. (n.d.). Introduction to Games-Based Learning.

Wing, L. A. U. (2015). Final Report for ENG4900 Honours Project A Study on the Effectiveness of Using Domino for Consolidating Vocabulary in Upper Primary ESL Classrooms. 1-90. 